medRxiv preprint doi: https://doi.org/10.1101/2022.01.05.22268819; this version posted January 6, 2022. The copyright holder for this preprint (which was not certified by peer review) is the author/funder, who has granted medRxiv a license to display the preprint in perpetuity.

It is made available under a CC-BY-NC-ND 4.0 International license.

\title{
1 Stability of plasma metabolomics over 10 years among women
}

2 Oana A. Zeleznik, Ph.D. ${ }^{1}$, Clemens Wittenbecher, Ph.D. ${ }^{2,3}$, Amy Deik, B.A. ${ }^{4}$, Sarah Jeanfavre,

3 M.S. ${ }^{4}$, Julian Avila-Pacheco, Ph.D. ${ }^{4}$, Bernard Rosner, Ph.D. ${ }^{1}$, Kathryn M. Rexrode, M.D. ${ }^{5}$, Clary

$4 \quad$ B. Clish, Ph.D. ${ }^{4}$, Frank B. Hu, Ph.D. ${ }^{2}$, A. Heather Eliassen, Sc.D. ${ }^{1,6}$

$5 \quad{ }^{1}$ Channing Division of Network Medicine, Brigham and Women's Hospital and Harvard Medical

6 School, Boston, MA, USA

$7 \quad{ }^{2}$ Department of Nutrition, Harvard T.H. Chan School of Public Health, Boston, MA, USA

$8 \quad{ }^{3}$ German Institute of Human Nutrition Potsdam-Rehbruecke, Nuthetal, Germany

$9 \quad{ }^{4}$ Broad Institute of Massachusetts Institute of Technology and Harvard, Cambridge, MA, USA

10 5Division of Women's Health, Brigham and Women's Hospital and Harvard Medical School,

11 Boston, MA, USA

$12{ }^{6}$ Department of Epidemiology, Harvard T.H. Chan School of Public Health, Boston, MA,

14 Correspondence:

15 Oana A. Zeleznik, PhD

Instructor in Medicine | Harvard Medical School 
medRxiv preprint doi: https://doi.org/10.1101/2022.01.05.22268819; this version posted January 6, 2022. The copyright holder for this preprint (which was not certified by peer review) is the author/funder, who has granted medRxiv a license to display the preprint in perpetuity.

It is made available under a CC-BY-NC-ND 4.0 International license .

\section{Abstract}

Background: In epidemiological studies, samples are often collected long before disease onset or outcome assessment. Understanding the long-term stability of biomarkers measured in these samples is crucial. We estimated within-person stability over 10 years of metabolites and metabolite features $(\mathrm{N}=5938)$ in the Nurses' Health Study (NHS): The primary dataset included 1880 women with 1184 repeated samples donated 10 years apart while the secondary dataset included 1456 women with 488 repeated samples donated 10 years apart.

Methods: We quantified plasma metabolomics using two liquid chromatography mass spectrometry platforms (lipids and polar metabolites) at the Broad Institute (Cambridge, MA). Intra-class correlations were used to estimate long-term stability (10 years) of metabolites and were calculated as the proportion of the total variability (within-person + between-person) attributable to between-person variability. Within-person variability was estimated among participants who donated two blood samples approximately 10 years apart while betweenperson variability was estimated among all participants.

Results: In the primary dataset, the median ICC was 0.43 ( $1^{\text {st }}$ quartile [Q1]: 0.36; $3^{\text {rd }}$ quartile [Q3]: 0.50) among known metabolites and 0.41 (Q1: 0.34; Q3: 0.48) among unknown metabolite features. The most stable (median ICCs: 0.54-0.57) metabolite classes were nucleosides, nucleotides and analogues, phosphatidylcholine plasmalogens, diglycerides, and cholesteryl esters. The least stable (median ICCs: 0.26-0.36) metabolite classes were lysophosphatidylethanolamines, lysophosphatidylcholines and steroid and steroid derivatives. Results in the secondary dataset were similar (Spearman correlation=0.87) to corresponding results in the primary dataset.

Conclusion: Within-person stability over 10 years is reasonable for lipid, lipid-related, and polar metabolites, and varies by metabolite class. Additional studies are required to estimate within-person stability over 10 years of other metabolites groups. 
medRxiv preprint doi: https://doi.org/10.1101/2022.01.05.22268819; this version posted January 6, 2022. The copyright holder for this preprint (which was not certified by peer review) is the author/funder, who has granted medRxiv a license to display the preprint in perpetuity.

It is made available under a CC-BY-NC-ND 4.0 International license .

\section{Introduction}

In epidemiological studies, samples are often collected long before disease onset or outcome assessment. Within the Nurses' Health Studies (NHS) and NHSII, several nested case-control studies investigated prospective associations of plasma biomarkers measured in samples collected $>10$ years before disease onset with risk of developing cancer and other chronic diseases. For example, total circulating carotenoids measured up to 20 years before diagnosis were associated with decreased risk of developing breast cancer ${ }^{1}$. In contrast, high plasma prolactin levels measured $\geq 10$ years before diagnosis were not associated with increased risk of breast cancer while measures $<10$ years before diagnosis were associated with increased risk $^{2}$, emphasizing that understanding how the timing of biomarkers is related to risk is critical to elucidating disease etiology. Thus, understanding the long-term within-person stability of biomarkers measured in these samples is crucial.

Metabolomics, which reflect the integrated effects of the genetic background, lifestyle and environmental factors ${ }^{3}$, are of particular interest in epidemiologic studies. Metabolites measured up to 23 years before diagnosis were associated with risk of ovarian cancer in NHS and $\mathrm{NHSII} 4,5$ reflecting long-term disease-biomarker associations. We reported previously on metabolomics short-term within-person stability in these cohorts ${ }^{6}$. However, data on the longterm within-person stability of metabolomics are lacking. Here, we assessed metabolomics within-person stability over 10 years in two separate prospective case-control studies nested within a large epidemiological study, the NHS. 
medRxiv preprint doi: https://doi.org/10.1101/2022.01.05.22268819; this version posted January 6, 2022. The copyright holder for this preprint (which was not certified by peer review) is the author/funder, who has granted medRxiv a license to display the preprint in perpetuity.

It is made available under a CC-BY-NC-ND 4.0 International license .

\section{Methods}

\section{Study Population}

In 1976, 121,701 female registered nurses aged 30-55y enrolled in the NHS with the return of a mailed questionnaire ${ }^{7}$. Participants have been followed biennially with questionnaires collecting information on reproductive history, lifestyle factors, diet, medication use, and new disease diagnoses. In 1989-1990, 32,826 NHS participants aged 43-69y contributed blood samples, as previously described ${ }^{8}$. In 2000-2002, 18,473 of these women aged 53-80y donated a second sample using a similar protocol.

The primary dataset was obtained from a prospective breast cancer case-control study nested within the NHS. Incident cases of breast cancer $(\mathrm{N}=940)$ were identified after the second blood collection among women who had no reported cancer (other than non-melanoma skin). In total, 1880 women donated a sample during the first blood collection and 1184 women donated a second blood sample approximately 10 years later.

The secondary dataset is from a prospective diabetes case-control study nested within the NHS. Incident cases of diabetes $(\mathrm{N}=728)$ were identified after the second blood collection. In total, 1456 women donated samples during the first blood collection and 488 women donated a second blood sample approximately 10 years later.

The study protocol was approved by the institutional review boards of the Brigham and Women's Hospital and Harvard T.H. Chan School of Public Health, and those of participating registries as required. The return of the self-administered questionnaire and blood sample was considered to imply consent.

\section{Blood collection methods}

The same protocol was used for both blood collections. Briefly, participants had their blood drawn in sodium heparin tubes at a nearby clinic or by their colleagues, and the blood 
medRxiv preprint doi: https://doi.org/10.1101/2022.01.05.22268819; this version posted January 6, 2022. The copyright holder for this preprint (which was not certified by peer review) is the author/funder, who has granted medRxiv a license to display the preprint in perpetuity.

It is made available under a CC-BY-NC-ND 4.0 International license .

samples were shipped with an ice pack via overnight courier to our laboratory. Whole blood samples were centrifuged ( 2500 RPM for 20 minutes at $4^{\circ} \mathrm{C}$ ) and aliquoted into $5 \mathrm{~mL}$ plasma, red blood cells and white blood cells cryotubes. Plasma samples are stored in the vapor phase of liquid nitrogen (LN2) freezers (temperature $\leq-130^{\circ} \mathrm{C}$; alarmed and monitored 24 hours a day) with LN2-rated gasketed screw tops since collection. At the time of blood collection, participants also completed a questionnaire regarding time since last meal and time of day when they completed blood collection

\section{Laboratory assays}

Metabolic profiles were assayed through a metabolomic profiling platform at the Broad Institute using a liquid chromatography tandem mass spectrometry (LC-MS) method designed to measure polar metabolites such as amino acids and lipids ${ }^{9-11}$. The relative abundance of each metabolite was determined by the integration of LC-MS peak areas, which are unitless numbers that are directly proportional to metabolite concentrations. For each measurement method (polar metabolites and lipids), pooled plasma reference samples were included every 20 samples and results were standardized using the ratio of the value of the sample to the value of the nearest pooled reference multiplied by the median of all reference values for the metabolite. In each dataset, samples were assayed in pairs, with matched case-control pairs (as sets) distributed randomly within the batch, and the order of the case and controls within each pair

111 randomly assigned. Therefore, the case and its control were always directly adjacent to each 112 other in the analytic run, thereby limiting variability in platform performance across matched 113 case-control pairs. In addition, YY quality control (QC) samples, to which the laboratory was

114 blinded, were also profiled. These were randomly distributed among the participants' samples. 
medRxiv preprint doi: https://doi.org/10.1101/2022.01.05.22268819; this version posted January 6, 2022. The copyright holder for this preprint (which was not certified by peer review) is the author/funder, who has granted medRxiv a license to display the preprint in perpetuity.

It is made available under a CC-BY-NC-ND 4.0 International license .

118

119

120

121

122

123

124

125

126

127

128

129

130

131

132

133

134

135

136

137

138

139

140

141

142
Exactive mass spectrometer (Thermo Fisher Scientific; Waltham, MA). Metabolites were extracted from plasma $(10 \mu \mathrm{L})$ using $90 \mu \mathrm{L}$ of acetonitrile/methanol/formic acid (74.9:24.9:0.2 v/v/v) containing stable isotope-labeled internal standards (valine-d8, Sigma-Aldrich; St. Louis, MO; and phenylalanine-d8, Cambridge Isotope Laboratories; Andover, MA). The samples were centrifuged $\left(10 \mathrm{~min}, 9,000 \times \mathrm{g}, 4^{\circ} \mathrm{C}\right)$, and the supernatants were injected directly onto a $150 \times 2$ mm, $3 \mu \mathrm{m}$ Atlantis HILIC column (Waters; Milford, MA). The column was eluted isocratically at a flow rate of $250 \mu \mathrm{L} / \mathrm{min}$ with $5 \%$ mobile phase A (10 mM ammonium formate and $0.1 \%$ formic acid in water) for 0.5 minute followed by a linear gradient to $40 \%$ mobile phase $B$ (acetonitrile with $0.1 \%$ formic acid) over 10 minutes. MS analyses were carried out using electrospray ionization in the positive ion mode using full scan analysis over $70-800 \mathrm{~m} / \mathrm{z}$ at 70,000 resolution and $3 \mathrm{~Hz}$ data acquisition rate. Other MS settings were: sheath gas 40, sweep gas 2, spray voltage $3.5 \mathrm{kV}$, capillary temperature $350^{\circ} \mathrm{C}$, S-lens $\mathrm{RF} 40$, heater temperature $300^{\circ} \mathrm{C}$, microscans 1, automatic gain control target 1e6, and maximum ion time $250 \mathrm{~ms}$. Metabolites measured with this method will be referred to as HILIC-positive metabolites.

Plasma lipids were profiled using a Shimadzu Nexera X2 U-HPLC (Shimadzu Corp.; Marlborough, MA). Lipids were extracted from plasma (10 $\mu \mathrm{L})$ using $190 \mu \mathrm{L}$ of isopropanol containing 1,2-didodecanoyl-sn-glycero-3-phosphocholine (Avanti Polar Lipids; Alabaster, AL). After centrifugation, supernatants were injected directly onto a $100 \times 2.1 \mathrm{~mm}, 1.7 \mu \mathrm{m}$ ACQUITY BEH C8 column (Waters; Milford, MA). The column was eluted isocratically with $80 \%$ mobile phase A (95:5:0.1 vol/vol/vol 10mM ammonium acetate/methanol/formic acid) for 1 minute followed by a linear gradient to $80 \%$ mobile-phase B (99.9:0.1 vol/vol methanol/formic acid) over 2 minutes, a linear gradient to $100 \%$ mobile phase B over 7 minutes, then 3 minutes at 100\% mobile-phase B. MS analyses were carried out using electrospray ionization in the positive ion mode using full scan analysis over $200-1100 \mathrm{~m} / \mathrm{z}$ at 70,000 resolution and $3 \mathrm{~Hz}$ data acquisition rate. Other MS settings were: sheath gas 50, in source CID $5 \mathrm{eV}$, sweep gas 5, spray voltage 3 
medRxiv preprint doi: https://doi.org/10.1101/2022.01.05.22268819; this version posted January 6, 2022. The copyright holder for this preprint (which was not certified by peer review) is the author/funder, who has granted medRxiv a license to display the preprint in perpetuity.

It is made available under a CC-BY-NC-ND 4.0 International license .

143

144

145

146

147

148

149

150

151

152

153

154

155

156

157

158

159

160

$\mathrm{kV}$, capillary temperature $300^{\circ} \mathrm{C}$, S-lens $\mathrm{RF} 60$, heater temperature $300^{\circ} \mathrm{C}$, microscans 1 , automatic gain control target 1e6, and maximum ion time $100 \mathrm{~ms}$. Lipid identities were denoted by total acyl carbon number and total double bond number. Metabolites measured with this method will be referred to as C8-positive metabolites.

Raw data from orbitrap mass spectrometers were processed using TraceFinder 3.3 software (Thermo Fisher Scientific; Waltham, MA) and Progenesis QI (Nonlinear Dynamics; Newcastle upon Tyne, UK). For each method, metabolite identities were confirmed using authentic reference standards or reference samples.

After exclusion of metabolites not stable with a delay in processing which is characteristic of the two blood collections ${ }^{6}(\mathrm{~N}=35)$ and those missing in $>10 \%$ of the participants who donated two samples (20 known compounds and 1069 unknown metabolite features), the primary dataset included 5938 metabolites (295 known compounds and 5643 unknown metabolite features) measured at both blood collections. 2519 lipids and lipid-related metabolites (153 known compounds and 2366 unknown metabolite features) were measured with the C8 column in positive mode while 3419 polar metabolites (142 known compounds and 3277 unknown metabolite features) were measured with the HILIC column in positive mode. Most of the known metabolites $(\mathrm{N}=253 ; 86 \%)$ and $47 \%(\mathrm{~N}=2655)$ of the unknown metabolite features had coefficients of variation $(C V)<25 \%$. All metabolites were included in this study. Similarly, after exclusion of metabolites not stable with a delay in processing which is characteristic of the two blood collections ${ }^{6}(\mathrm{~N}=34)$ and those missing in $>10 \%$ of the participants who donated two samples (16 known compounds and 427 unknown metabolite features), the secondary dataset included 3209 polar metabolites (202 known compounds and 3007 unknown metabolite features) measured at both blood collections. The secondary dataset did not include lipids and lipid-related metabolites. Most of the known metabolites ( $\mathrm{N}=171 ; 85 \%)$ and $44 \%$ 
medRxiv preprint doi: https://doi.org/10.1101/2022.01.05.22268819; this version posted January 6, 2022. The copyright holder for this preprint (which was not certified by peer review) is the author/funder, who has granted medRxiv a license to display the preprint in perpetuity.

It is made available under a CC-BY-NC-ND 4.0 International license .

167

168

169

$(\mathrm{N}=1326)$ of the unknown metabolite features had $\mathrm{CV}<25 \%$. All metabolites were included in this study.

\section{Statistical Analysis}

Metabolite values were transformed to probit scores within in each blood collection and dataset. We estimated within-person stability over 10 years by calculating intra-class correlation (ICC) using liner mixed models with participant IDs as a random effect. We followed the approach developed by Dr. Rosner et. al ${ }^{12}$ to estimate ICCs on the probit scale and transform these back to the ranked scale. Within-person variability was estimated among participants who donated two blood samples approximately 10 years apart $(\mathrm{N}=1184)$ while between-person variability was estimated among all participants $(\mathrm{N}=1880)$. ICCs were calculated as the proportion of the total variability (within-person + between-person) attributable to betweenperson variability. We also calculated median \% change in metabolite levels over 10 years. In sensitivity analyses, we restricted to fasting women ( $N=1309$ of which 765 donated 2 samples), women with stable BMI $\left(\leq 2 \mathrm{~kg} / \mathrm{m}^{2}\right.$ change in BMI between the two blood collections, $\left.\mathrm{N}=706\right)$, women with change in BMI $\left(>2 \mathrm{~kg} / \mathrm{m}^{2}\right.$ change in BMl between the two blood collections, $\left.\mathrm{N}=478\right)$, postmenopausal women not using postmenopausal hormone therapy at either timepoint $(\mathrm{N}=577$ of which 223 donated 2 samples), and to women without breast cancer at both blood collections ( $N=940$ of which 592 donated 2 samples). The secondary dataset included only women who were fasting for $>8$ hours. To assess differences in ICCs between the two datasets, we calculated \% absolute change in ICCs between the primary and secondary dataset.

\section{Results}

\section{Study population characteristics}

Women in the primary dataset had a mean age of 56 years at the first blood collection $(\mathrm{N}=1880)$ and 66 years at the second blood collection $(\mathrm{N}=1184)$. Participant characteristics were similar at the two blood collections (Table 1) with some exceptions: more women reported 
medRxiv preprint doi: https://doi.org/10.1101/2022.01.05.22268819; this version posted January 6, 2022. The copyright holder for this preprint (which was not certified by peer review) is the author/funder, who has granted medRxiv a license to display the preprint in perpetuity.

It is made available under a CC-BY-NC-ND 4.0 International license .

192

193

194

195

196

Table 1: Characteristics of study participants by blood collection in the primary dataset.

\begin{tabular}{|lll|}
\hline & First collection & Second collection \\
\hline N & 1880 & 1184 \\
\hline Bge, $\mathbf{y}$ & $55.57(6.92)$ & $66.46(6.87)$ \\
\hline Physical activity, MET-hrs/wk & $25.37(4.53)$ & $26.57(5.11)$ \\
\hline Alcohol consumption, g/day & $16.34(20.00)$ & $19.58(20.78)$ \\
\hline AHEl^ & $6.71(10.95)$ & $5.81(9.45)$ \\
\hline Menopausal status, \% & $47.31(10.67)$ & $50.16(9.98)$ \\
\hline Premenopausal & & \\
\hline Postmenopausal, no PMH\# use & $577(30.7)$ & $374(31.6)$ \\
\hline Postmenopausal, PMH\# use & $587(31.2)$ & $788(66.6)$ \\
\hline Missing/Dubious & $237(12.6)$ & $14(1.2)$ \\
\hline Fasting (>8h), \% & $1309(69.6)$ & $1062(89.7)$ \\
\hline Smoking, \% & & \\
\hline Never & $888(47.4)$ & $551(46.7)$ \\
\hline Past & $748(39.9)$ & $575(48.7)$ \\
\hline Current & $238(12.7)$ & $55(4.7)$ \\
\hline Race, \% & & \\
\hline White & $1853(98.6)$ & $1173(99.1)$ \\
\hline Black & $14(0.7)$ & $4(0.3)$ \\
\hline Asian & $10(0.5)$ & $5(0.4)$ \\
\hline Other/missing & $3(0.2)$ & $2(0.2)$ \\
\hline AAternative Healthy Eating & & $8(0.7)$ \\
\hline
\end{tabular}

$\wedge$ Alternative Healthy Eating Index, calculated without alcohol consumption

\#Postmenopausal Hormone

compared to the first blood collection. Women in the secondary dataset (first collection $\mathrm{N}=1456$,

second collection $N=488$ ) were similar to the fasting women (first collection $N=1309$, second

collection $\mathrm{N}=1062$ ) in the primary dataset (Supplementary Table 1).

being postmenopausal, past smokers and fasting $>8$ hours at the second blood collection

Metabolomics stability over 10 years in the primary dataset

For known metabolites, the median ICC was $0.43\left(1^{\text {st }}\right.$ quartile [Q1]: 0.36; $3^{\text {rd }}$ quartile 
medRxiv preprint doi: https://doi.org/10.1101/2022.01.05.22268819; this version posted January 6, 2022. The copyright holder for this preprint (which was not certified by peer review) is the author/funder, who has granted medRxiv a license to display the preprint in perpetuity.

It is made available under a CC-BY-NC-ND 4.0 International license.

0.38; Q3: 0.51) while for the unknown metabolite features it was 0.41 (Q1: 0.35; Q3: 0.47;

Figure 1). Among polar metabolites, the median ICC for known metabolites was 0.42 (Q1: 0.33 ; Q3: 0.49) while for the unknown metabolite features it was 0.41 (Q1: 0.34; Q3: 0.48; Figure 1). The median ICC was 0.43 (Q1: 0.36; Q3: 0.50) among metabolites with CV<25\% and 0.39 (Q1: 0.33; Q3:0.46) among metabolites with CV $\geq 25 \%$. The median \% difference in known metabolite levels between the two collections, calculated from the raw values, was $-5.25 \%(\mathrm{Q} 1:-14.80 \%$, Q3:0.92\%; Supplementary Table 2). The median \% difference in unknown metabolite feature levels between the two collections, calculated from the raw values, was $0.03 \%(Q 1:-6.80 \%$, Q3:4.13\%; Supplementary Table 2).

Figure 1: Metabolomics stability over 10 years by measurement method (lipid and lipid-related vs. polar metabolites) and known metabolites ( $N=295)$ vs. unknown metabolite features $(\mathrm{N}=5643)$.

\section{Lipid and lipid-related metabolites}

$0.75-$ metabolites metabolite features
$0.00-$

Known

$U^{0.50-}$

$0.25-$

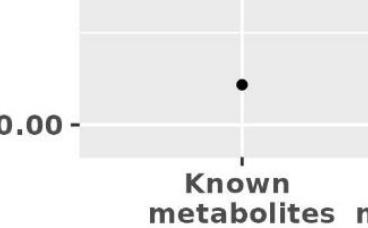

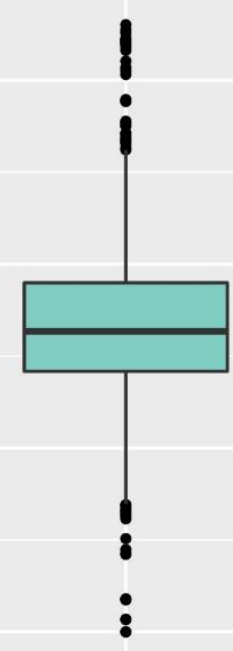

Unknown

\section{Polar metabolites}

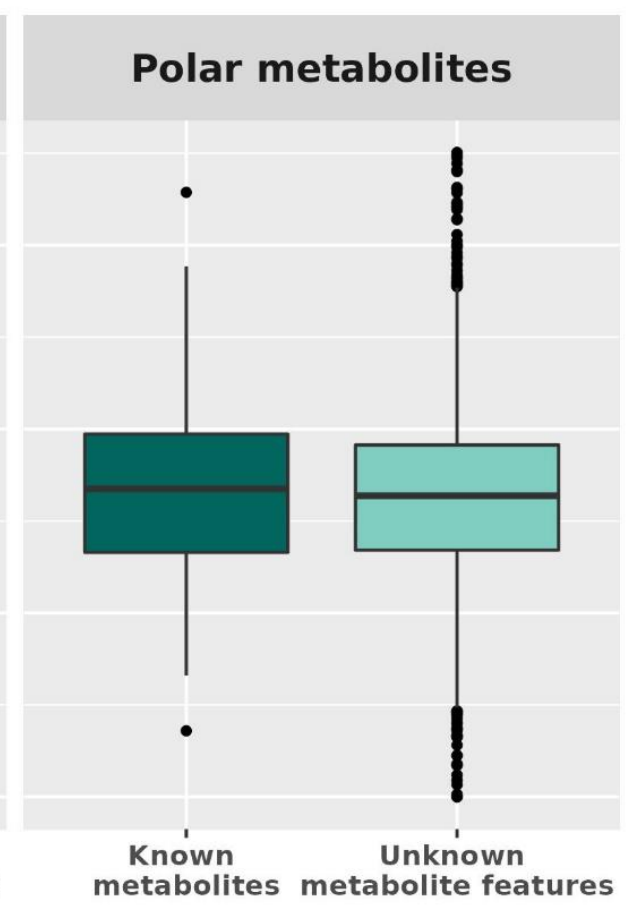

Known metabolites metabolite features

\section{(1)}

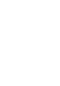


medRxiv preprint doi: https://doi.org/10.1101/2022.01.05.22268819; this version posted January 6, 2022. The copyright holder for this preprint (which was not certified by peer review) is the author/funder, who has granted medRxiv a license to display the preprint in perpetuity.

It is made available under a CC-BY-NC-ND 4.0 International license .

diglycerides (DG; median ICC: 0.53; Q1: 0.51; Q3: 0.54), and cholesteryl esters (CE; median

ICC: 0.53; Q1: 0.51; Q3: 0.56). The least stable metabolite classes were steroids and steroid derivatives (median ICC: 0.26; Q1: 0.25; Q3: 0.28), lysophosphatidylcholines (LPC; median ICC: 0.36; Q1: 0.27; Q3: 0.40) and lysophosphatidylethanolamines (LPE; median ICC: 0.36; Q1: 0.33; Q3: 0.38).

Figure 2: Metabolomics stability over 10 years by metabolite class. Results from known metabolites are included in this figure. Metabolomics classes with less than three metabolites were added to the class Other.
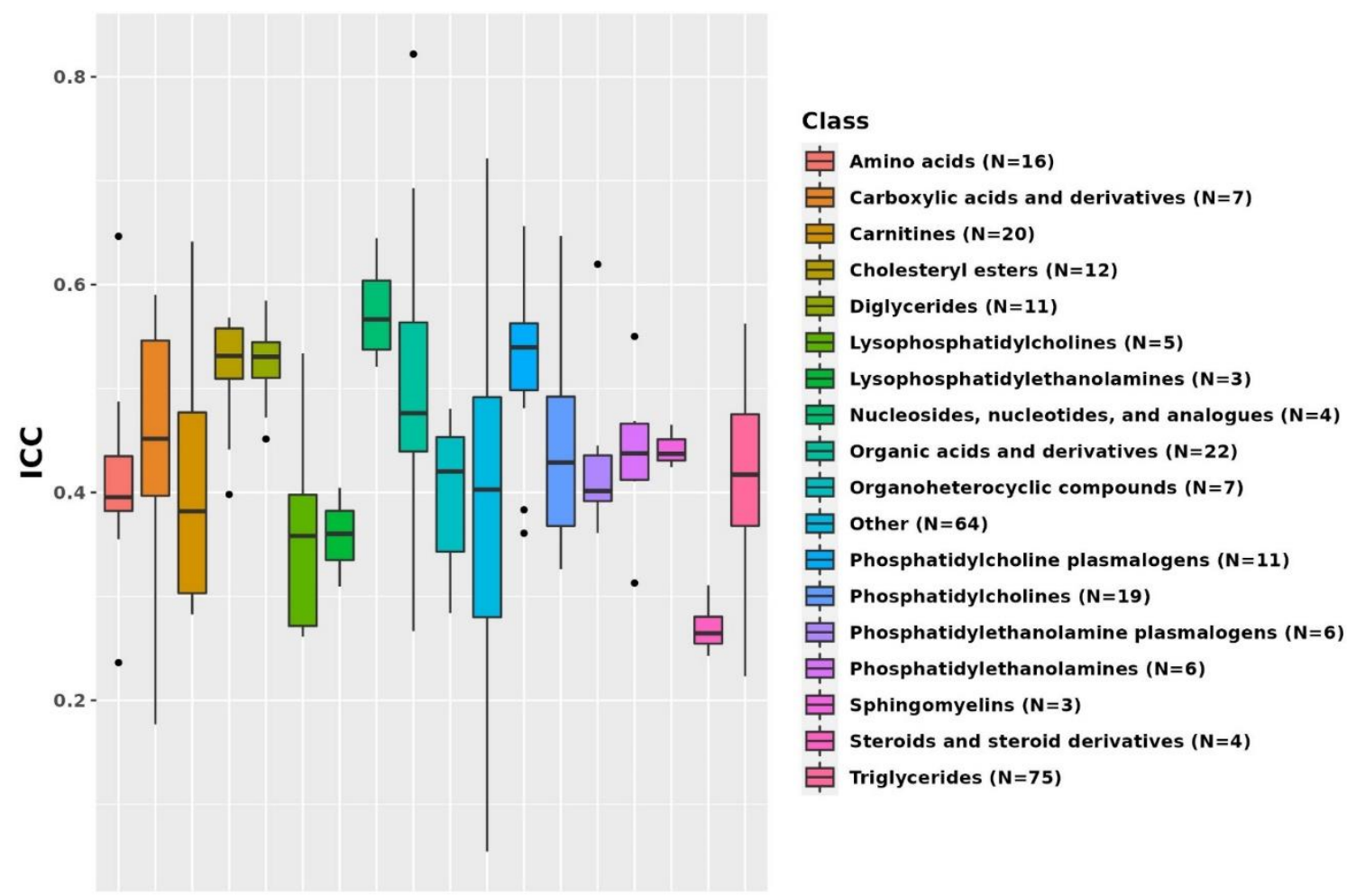

We observed similar ICCs across participant strata in sensitivity analyses (Figure 3,

Supplementary Table 2, and Supplementary Figure 1). ICCs of known metabolites estimated among all women (median ICC: 0.43, Q1: 0.36; Q3: 0.50) were similar to those estimated among fasting women (median ICC: 0.45, Q1: 0.37; Q3: 0.52), women with stable BMI (median ICC: 0.43, Q1: 0.36; Q3: 0.51) and women with a change in BMI (median ICC: 0.41, Q1: 0.33; Q3: 0.48). A similar pattern was observed for unknown metabolite features (all women: median 
medRxiv preprint doi: https://doi.org/10.1101/2022.01.05.22268819; this version posted January 6, 2022. The copyright holder for this preprint (which was not certified by peer review) is the author/funder, who has granted medRxiv a license to display the preprint in perpetuity.

It is made available under a CC-BY-NC-ND 4.0 International license .

ICC: 0.41 (Q1:0.34; Q3:0.48); fasting women: median ICC: 0.42 (Q1: 0.35; Q3: 0.49); women with stable BMI: median ICC: 0.42 (Q1: 0.35; Q3: 0.48); women with unstable BMI: median ICC: 0.40 (Q1: 0.33; Q3: 0.47)). Among postmenopausal women not using postmenopausal hormone therapy at either collection, the median ICC was 0.44 (Q1: 0.36; Q3: 0.53) for known metabolites and 0.41 (Q1: 0.33; Q3: 0.49) for unknown metabolite features (data not shown). Among control samples only, the median ICC was 0.44 (Q1: 0.37; Q3: 0.51) for known metabolites and 0.41 (Q1: 0.35; Q3: 0.49) for unknown metabolite features (data not shown). Notably, metabolites stable among all women were also stable when assessed in different participant strata (for example, N6,N6-dimethyllysine ICC ranges between 0.82 and 0.84 across participant strata; Table 2). Similarly, metabolites with low ICC among all women were also not stable when assessed in the different participant strata (for example, palmitoylethanolamide ICC ranges between 0.03 and 0.06 across subgroups; Table 2).

Figure 3: Metabolomics stability over 10 years by known metabolites ( $N=295)$ vs. unknown metabolite features $(\mathrm{N}=\mathbf{5 6 4 3}$ ). ICCs were estimated among all participants ( $N=1880$ of which 1184 donated 2 samples), fasting participants ( $\mathrm{N}=1309$ of which 765 donated 2 samples), and among participants with stable $(\mathrm{N}=706)$ or unstable $\mathrm{BMI}(\mathrm{N}=478$ samples). The stable $\mathrm{BMI}$ group includes participants with $\leq 2 \mathrm{~kg} / \mathrm{m}^{2}$ change in BMI between the two blood collections. The unstable BMI group includes participants with $>2 \mathrm{~kg} / \mathrm{m}^{2}$ change in BMI between the two blood collections.

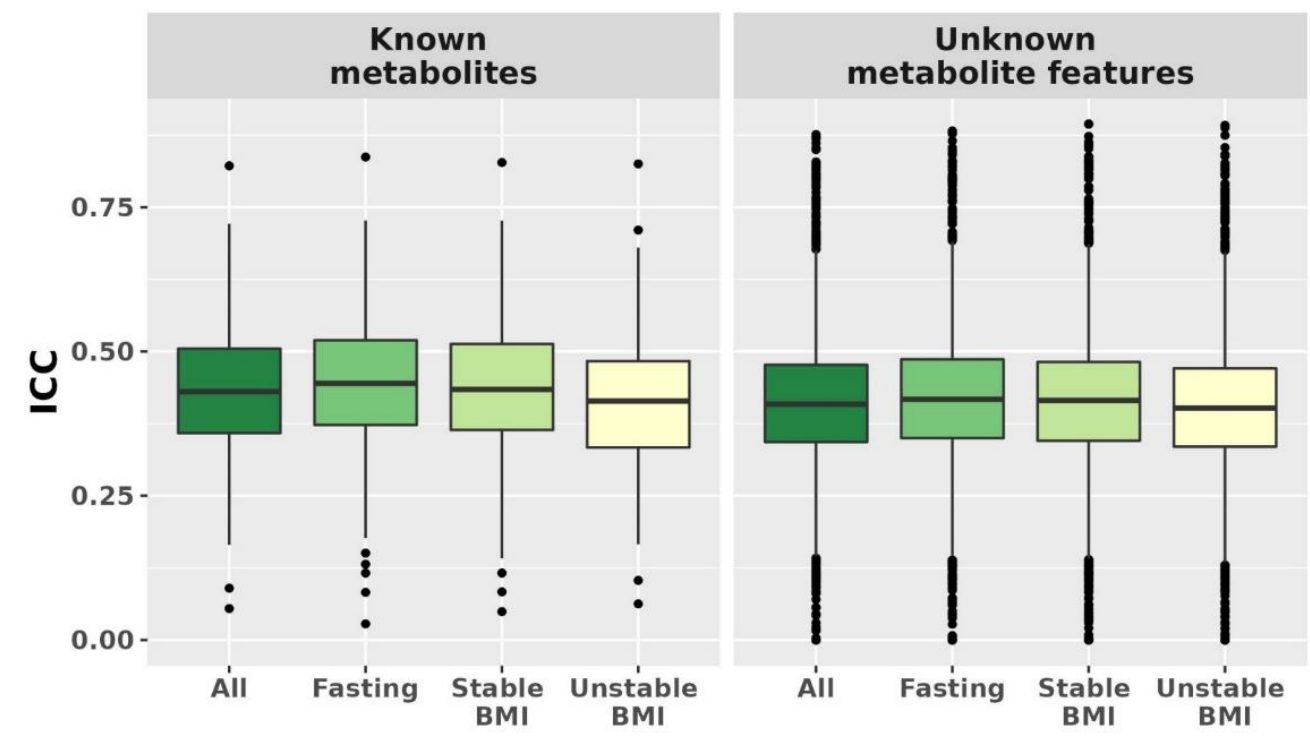


medRxiv preprint doi: https://doi.org/10.1101/2022.01.05.22268819; this version posted January 6, 2022. The copyright holder for this preprint (which was not certified by peer review) is the author/funder, who has granted medRxiv a license to display the preprint in perpetuity.

It is made available under a CC-BY-NC-ND 4.0 International license .

Table 2: Most and least stable metabolites. ICCs were estimated among four participant subgroups: all participants ( $\mathrm{N}=1184$ repeated samples and $\mathrm{N}=696$ unique samples), fasting participants ( $\mathrm{N}=765$ repeated and $\mathrm{N}=544$ unique samples), and among participants with stable ( $\mathrm{N}=706$ repeated samples) or unstable $\mathrm{BMI}\left(\mathrm{N}=478\right.$ repeated samples). The stable $\mathrm{BMI}$ group includes participants with $\leq 2 \mathrm{~kg} / \mathrm{m}^{2}$

258 difference in BMI between the two blood collections. The unstable BMI group includes participants with $>2 \mathrm{~kg} / \mathrm{m}^{2}$ difference in BMI between the two blood collections.

Intra-class correlation

\begin{tabular}{llllll} 
Metabolite name & Metabolite class & All & Fasting & $\begin{array}{l}\text { Stable } \\
\text { BMI }\end{array}$ & $\begin{array}{l}\text { Unstable } \\
\text { BMI }\end{array}$ \\
\hline N6,N6-dimethyllysine & Organic acids and derivatives & 0.82 & 0.84 & 0.83 & 0.83 \\
\hline DMGV & Other & 0.72 & 0.73 & 0.73 & 0.71 \\
\hline N-acetylornithine & Organic acids and derivatives & 0.69 & 0.72 & 0.7 & 0.68 \\
\hline C34:2 PC plasmalogen & Phosphatidylcholine plasmalogens & 0.66 & 0.67 & 0.66 & 0.61 \\
C38:4 PC & Phosphatidylcholines & 0.65 & 0.66 & 0.66 & 0.63 \\
\hline glycine & Amino acids & 0.65 & 0.64 & 0.65 & 0.62 \\
C5-DC carnitine & Carnitines & 0.64 & 0.63 & 0.66 & 0.62 \\
\hline N4-acetylcytidine & Nucleosides, nucleotides, and & & & & \\
\hline ADMA/SDMA & analogues & 0.64 & 0.62 & 0.68 & 0.62 \\
\hline C36:1 PE plasmalogen & Organic acids and derivatives & 0.62 & 0.63 & 0.66 & 0.65 \\
\hline
\end{tabular}

1-methylhistidine

4-hydroxyhippurate

acetaminophen

guanosine

allantoin

hydroxyproline

methyl $\mathrm{N}$-methylanthranilate

trimethylamine- $\mathrm{N}$-oxide

ectoine

palmitoylethanolamide

\section{Other}

Other

Other

Other

Other

Carboxylic acids and derivatives

Other

Other

Other

Other $\begin{array}{ll}0.21 & 0.18\end{array}$

$0.21 \quad 0.19$

$0.2 \quad 0.18$

$0.2 \quad 0.20$

$0.18 \quad 0.21$

$0.18 \quad 0.12$

$0.17 \quad 0.13$

$0.16 \quad 0.15$

$0.09 \quad 0.08$

$0.05 \quad 0.03$

\subsection{1}

0.18

0.21

0.17

0.15

0.17

0.14

0.12

0.08

0.05
0.25

0.26

0.21

0.23

0.20

0.17

0.22

0.24

0.10

0.06

\section{Metabolomics stability over 10 years in the secondary dataset}


medRxiv preprint doi: https://doi.org/10.1101/2022.01.05.22268819; this version posted January 6, 2022. The copyright holder for this preprint (which was not certified by peer review) is the author/funder, who has granted medRxiv a license to display the preprint in perpetuity.

It is made available under a CC-BY-NC-ND 4.0 International license .

Q3: 0.51), similar to the median ICC of 0.43 (Q1: 0.35; Q3: 0.52) among unknown metabolite features. Among known metabolites for which we were able to estimate ICCs in both datasets ( $\mathrm{N}=105), 52(50 \%)$ metabolites had \% ICC absolute difference <10\% and $82(78 \%)$ had \% absolute difference $<20 \%$. The metabolites with the lowest $\%$ absolute ICC difference between

271 the two datasets were 1,7-dimethyluric acid (primary dataset ICC: 0.42 ; secondary dataset ICC:

273 (primary dataset ICC: 0.60; secondary dataset ICC: 0.60). Similarly, 17 metabolites ranked among the top 25 most stable metabolites in the primary dataset were also ranked among the 25 most stable metabolites in the secondary dataset.

Figure 4: Metabolomics stability over 10 years in the primary and secondary datasets. The primary dataset was restricted to polar metabolites and fasting women to match the secondary dataset. Intraclass correlations (ICCS) in the two datasets are shown as boxplots (panel A) and by metabolite class in a scatter plot (panel B). The correlation was estimated using Spearman's rank correlation coefficient.

A

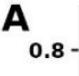

$0.2-$

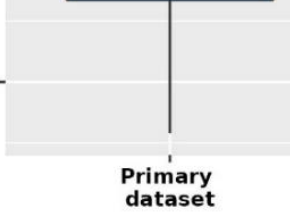

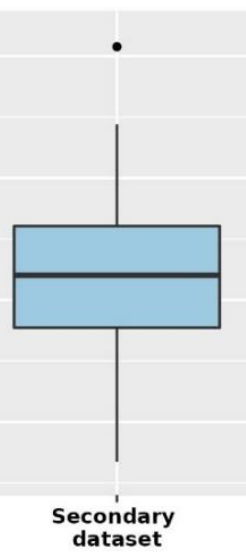

281

282

\section{Discussion}
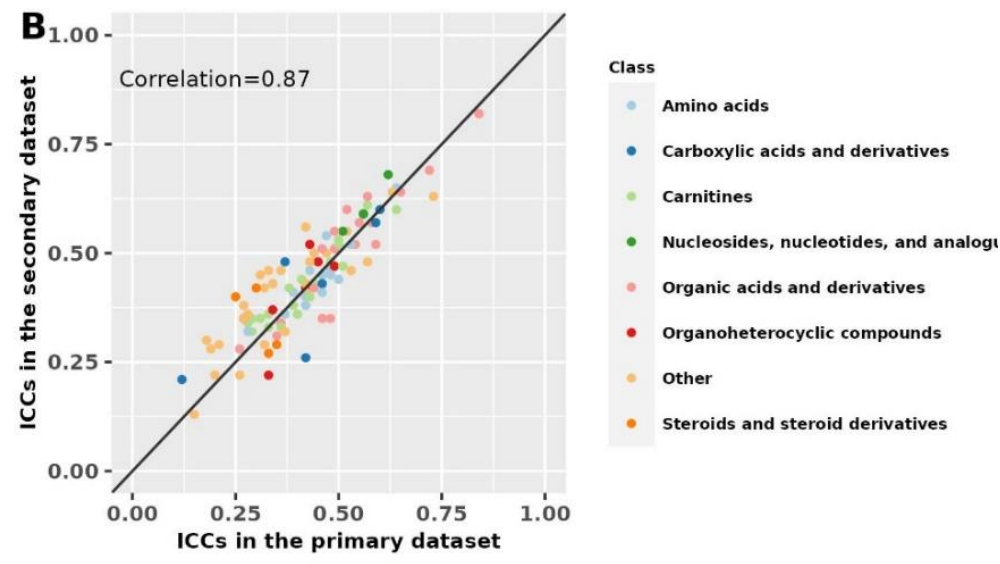

We estimated within-person stability over ten years for 5938 metabolites (295 known compounds and 5643 unknown metabolite features) among 1880 women. Most metabolites were reasonably stable over ten years with a median ICC of 0.43 for known metabolites and 0.41 from unknown metabolite features. Within-person stability over ten years varied by 
medRxiv preprint doi: https://doi.org/10.1101/2022.01.05.22268819; this version posted January 6, 2022. The copyright holder for this preprint (which was not certified by peer review) is the author/funder, who has granted medRxiv a license to display the preprint in perpetuity.

It is made available under a CC-BY-NC-ND 4.0 International license .

metabolite class. In secondary analyses, we performed a partial replication of polar metabolites in another data set of 1456 fasting women; findings were similar.

To the best of our knowledge, this is the first study to assess within-person stability of metabolomic profiles over 10 years. We have assessed within-person stability of metabolites over shorter periods of times, 1-2 years ${ }^{6}$. Notably, although the within-person stability was attenuated, the metabolite classes that were the most stable over 1-2 years were also the most stable over 10 years. For example, cholesteryl esters, phosphatidylcholine plasmalogens and diglycerides had the high median ICCs over 1 -2 years (median ICC: $0.76,0.76,0.73$ ) and over 10 years (median ICC: $0.53,0.55,0.53$ ). Nucleosides, nucleotides, and analogues were the most stable class over 10y $(10 y \mathrm{ICC}=0.57,1-2 \mathrm{y} I C C=0.55)$. Steroid and steroid derivatives was the least stable class over $1-2$ years (median ICC $=0.36)$ and over 10 years $($ median ICC $=$ 0.26).

Our results show that although the within-person stability decreases over time, metabolites are reasonably stable over 10 years. The reduced within-person stability over 10 years compared to 1-2 years is due to multiple sources of variation. True changes in metabolite levels over long periods of time are the most important one. Changes over 10 years in personal, behavioral, and lifestyle factors such as age, BMI, menopausal status, exposure to postmenopausal hormone therapy, diet, physical activity are likely to affect metabolite levels. For example, acetaminophen, a drug often used sporadically for different types of aches and pains, had a low with-in-person stability, likely reflecting different windows of exposure. Furthermore, some diet related metabolites (e.g. trimethylamine-N-oxide (TMO) ${ }^{13}$, pipecolic acid $^{14}$ ) tended to show low within-person stability over 10 years. Notably, within person stability over time among triglycerides (TAG) varied by saturation level and length of the fatty acyl chains. Most highly unsaturated TAGs with long fatty acyl chains, which are associated with long-term vegetable intake ${ }^{14}$, tended to be more stable over time compared to less unsaturated 
medRxiv preprint doi: https://doi.org/10.1101/2022.01.05.22268819; this version posted January 6, 2022. The copyright holder for this preprint (which was not certified by peer review) is the author/funder, who has granted medRxiv a license to display the preprint in perpetuity.

It is made available under a CC-BY-NC-ND 4.0 International license .

312 TAGs with shorter fatty acyl chains. While changes in behaviors and exposures result in a

313 reduced 10 years within-person stability of metabolites, it is important to note that we expect

314 changes in metabolite levels in response to changes in these factors. Furthermore, we study

315 metabolites to identify new risk and disease biomarkers because they reflect changes in these

316 factors and are considered a representation of the metabolic state of an individual, the

317 integrated effects of their genetic background, lifestyle, and environmental exposures ${ }^{3}$. A critical

318 feature of some of the most widely applied clinical disease risk markers, such as standard blood

319 lipids, is their responsiveness to pharmacological and lifestyle-based risk prevention.

Long-term storage may represent another source of variation. However, the samples in

321 these cohorts are stored at ultra-low temperatures $\left(\leq-196^{\circ} \mathrm{C}\right)$ which were shown to limit the

322 negative effects of long-term storage ${ }^{15}$. Additionally, we have identified metabolites measured in

323 these long-term stored samples that were significantly associated with cancer and other chronic

324 diseases in multiple studies (e.g., pancreatic ${ }^{16}$, ovarian ${ }^{4,5}$, breast ${ }^{17,18}$ and prostate cancer ${ }^{19}$,

325 rheumatoid arthritis ${ }^{20}$ and cardiovascular disease ${ }^{21}$ ), suggesting that storage time does not

326 substantially impact biomarker-disease associations. Furthermore, for a considerable subset of

327 metabolites (e.g., cotinine, trigonelline, caffeine, pantothenate, C45:3 TAG, C54:9 TAG), we

328 also observed relatively large median \% differences over 10 years $(-47 \% /+58 \%)$ and, at the

329 same time, reasonably high ICCs $(>0.4)$, suggesting that potential changes in metabolite levels

330 due to long term-storage are similar across individuals.

For a subset of metabolites, two additional sources of variation have to be considered.

332 To leverage the large coverage of the assay, we did not exclude metabolites with low technical

333 reproducibility from the analysis. Furthermore, the samples in this analysis are subject to

334 delayed processing (24-48 hours after sample collection). We excluded metabolites where we

335 have documented variation with a delay in processing ${ }^{6}$, but this information was not available for 
medRxiv preprint doi: https://doi.org/10.1101/2022.01.05.22268819; this version posted January 6, 2022. The copyright holder for this preprint (which was not certified by peer review) is the author/funder, who has granted medRxiv a license to display the preprint in perpetuity.

It is made available under a CC-BY-NC-ND 4.0 International license .

all known metabolites, and not available for any of the unknown metabolite features. Notably, both factors would result in a potential underestimation of long-term within-person stability.

The 10-year within-person stability of metabolites is similar to other plasma biomarkers measured in the NHS. For example, postmenopausal hormone levels (estradiol ICC $=0.69$, testosterone ICC $=0.71$, sex hormone-binding globulin ICC $=0.74$, and dehydroepiandrosterone sulfate ICC $=0.54)^{22}, 25$-hydroxyvitamin $\mathrm{D}(\mathrm{ICC}=0.51)^{23}$ and prolactin $(\mathrm{ICC}=0.39)^{2}$ all showed high or moderate within-person reproducibility over 10 years, whereas dietary biomarkers such as carotenoids (ICCs ranged between 0.3 for $\beta$-carotene to 0.54 for lutein and zeaxanthin) ${ }^{1}$ and fluorescent oxidation products (ICCs range from 0.14 to 0.30$)^{24}$ showed moderate or modest long-term within-person stability. While long-term stability should be factored into result interpretation, many of the most predictive and widely used biomarkers have similar within-person stability over 10 years in this cohort. For example, plasma cholesterol has a 10 years ICC of 0.39 and is highly predictive of coronary artery disease risk in our ${ }^{25-27}$ and other cohorts.

Our study has several strengths and limitations. We were able to assess within-person stability over 10 years for over 295 known metabolites (polar metabolites, and lipids and lipidrelated metabolites) and 5643 unknown metabolite features. However, our study did not include other metabolite groups such as fatty acids, carbohydrates, alcohols, and vitamins. We had a large sample size and were able to conduct a partial replication for a subset of the measured metabolites among fasting women, but our study included mostly Caucasian women limiting its generalizability. It should also be noted that the samples used in this analysis were subject to delayed processing (blood collection characteristic in the NHS). While we excluded metabolites known to vary with a delay in processing, this information was not available for all analyzed metabolites. Additionally, we did not exclude metabolites with low technical reproducibility. Due to these factors, the ICCs presented here may include variation due to technical reproducibility 
medRxiv preprint doi: https://doi.org/10.1101/2022.01.05.22268819; this version posted January 6, 2022. The copyright holder for this preprint (which was not certified by peer review) is the author/funder, who has granted medRxiv a license to display the preprint in perpetuity.

It is made available under a CC-BY-NC-ND 4.0 International license .

361

362

363

364

365

366

367

368

369

370

371

372

373

374

375

376

377 help: AL, AZ, AR, CA, CO, CT, DE, FL, GA, ID, IL, IN, IA, KY, LA, ME, MD, MA, MI, NE, NH,

$378 \mathrm{NJ}, \mathrm{NY}, \mathrm{NC}, \mathrm{ND}, \mathrm{OH}, \mathrm{OK}, \mathrm{OR}, \mathrm{PA}, \mathrm{RI}, \mathrm{SC}, \mathrm{TN}, \mathrm{TX}, \mathrm{VA}, \mathrm{WA}, \mathrm{WY}$. The authors assume full

and/or differential delay in processing between the two blood collections which can potentially result in an underestimation of within-person stability over time.

In summary, our study showed that metabolites are reasonably stable over 10 years, a time interval characteristic of prospective epidemiologic studies of chronic disease. In a secondary dataset, we were able to replicate our findings for a subset of metabolites among fasting women. Stability over ten years varied by metabolite class. While the 10 years stability of metabolites should be an important factor when interpreting results, it is equally important to consider the sources of variation that influence long-term within-person stability of metabolites.

Findings from this study represent a comprehensive resource for the design of future studies into disease risk associations of specific metabolites and/or metabolite classes.

Acknowledgements. This study was funded by the National Institutes of Health (UM1 CA186107, P01 CA087969, R01 CA49449, R01 DK112940). The content is solely the responsibility of the authors and does not necessarily represent the official views of the National Institutes of Health. We would like to thank the participants and staff of the Nurses' Health Studies for their valuable contributions as well as the following state cancer registries for their responsibility for analyses and interpretation of these data. 
medRxiv preprint doi: https://doi.org/10.1101/2022.01.05.22268819; this version posted January 6, 2022. The copyright holder for this preprint (which was not certified by peer review) is the author/funder, who has granted medRxiv a license to display the preprint in perpetuity.

It is made available under a CC-BY-NC-ND 4.0 International license . Clin Nutr 101, 1197-1205 (2015).

2. Tworoger, S.S., et al. A 20-year prospective study of plasma prolactin as a risk marker of breast cancer development. Cancer Res. 73, 4810-4819 (2013).

3. Krumsiek, J., Bartel, J. \& Theis, F.J. Computational approaches for systems metabolomics. Current opinion in biotechnology 39, 198-206 (2016).

4. Zeleznik, O.A., et al. Circulating Lysophosphatidylcholines, Phosphatidylcholines, Ceramides, and Sphingomyelins and Ovarian Cancer Risk: A 23-Year Prospective Study. J Natl Cancer Inst (2019).

5. Zeleznik, O.A., et al. A prospective analysis of circulating plasma metabolites associated with ovarian cancer risk. Cancer Res. (2020).

6. Townsend, M.K., et al. Reproducibility of metabolomic profiles among men and women in 2 large cohort studies. Clinical chemistry 59, 1657-1667 (2013).

7. Hankinson, S.E., et al. Plasma prolactin levels and subsequent risk of breast cancer in postmenopausal women. J. Natl. Cancer Inst. 91, 629-634 (1999).

8. Tworoger, S.S., Sluss, P. \& Hankinson, S.E. Association between plasma prolactin concentrations and risk of breast cancer among predominately premenopausal women. Cancer research 66, 2476-2482 (2006).

400

401

402

403

9. Mascanfroni, I.D., et al. Metabolic control of type 1 regulatory T cell differentiation by AHR and HIF1- $\alpha$. Nature medicine 21, 638 (2015).

10. O'sullivan, J.F., et al. Dimethylguanidino valeric acid is a marker of liver fat and predicts diabetes. The Journal of clinical investigation 127, 4394-4402 (2017).

11. Paynter, N.P., et al. Metabolic predictors of incident coronary heart disease in women. Circulation 137, 841-853 (2018).

12. Rosner, B. \& Glynn, R.J.J.S.i.m. Interval estimation for rank correlation coefficients based on the probit transformation with extension to measurement error correction of correlated ranked data. 26, 633-646 (2007).

13. Bennett, B.J., et al. Trimethylamine-N-oxide, a metabolite associated with atherosclerosis, exhibits complex genetic and dietary regulation. 17, 49-60 (2013).

14. Wang, F., et al. Mapping the Metabolic Profiles of Long-Term Vegetable, Fruit, and Fruit Juice Consumption. 4, 787-787 (2020).

15. Tworoger, S.S. \& Hankinson, S.E. Use of biomarkers in epidemiologic studies: minimizing the influence of measurement error in the study design and analysis. Cancer Causes \& Control 17, 889-899 (2006).

16. Mayers, J.R., et al. Elevation of circulating branched-chain amino acids is an early event in human pancreatic adenocarcinoma development. Nature medicine 20, 1193-1198 (2014).

17. Zeleznik, O.A., et al. Branched chain amino acids and risk of breast cancer. medRxiv, 2020.2008.2031.20185470 (2020).

18. Zeleznik, O.A., et al. Circulating amino acids and amino acid-related metabolites and risk of breast cancer among predominantly premenopausal women. NPJ breast cancer 7, 1-10 (2021).

19. Dickerman, B.A., et al. A metabolomics analysis of adiposity and advanced prostate cancer risk in the Health Professionals Follow-up Study. Metabolites 10, 99 (2020).

20. Chu, S.H., et al. Circulating plasma metabolites and risk of rheumatoid arthritis in the Nurses' Health Study. Rheumatology 59, 3369-3379 (2020).

21. Li, J., et al. The Mediterranean diet, plasma metabolome, and cardiovascular disease risk. European heart journal 41, 2645-2656 (2020). 
medRxiv preprint doi: https://doi.org/10.1101/2022.01.05.22268819; this version posted January 6, 2022. The copyright holder for this preprint (which was not certified by peer review) is the author/funder, who has granted medRxiv a license to display the preprint in perpetuity. It is made available under a CC-BY-NC-ND 4.0 International license.

22. Zhang, X., Tworoger, S.S., Eliassen, A.H. \& Hankinson, S.E. Postmenopausal plasma sex hormone levels and breast cancer risk over 20 years of follow-up. Breast cancer research and treatment 137, 883-892 (2013).

23. Eliassen, A.H., et al. Plasma 25-hydroxyvitamin D and risk of breast cancer in women followed over 20 years. Cancer Res. 76, 5423-5430 (2016).

24. Fortner, R.T., Tworoger, S.S., Wu, T. \& Eliassen, A.H. Plasma florescent oxidation products and breast cancer risk: repeated measures in the Nurses' Health Study. Breast cancer research and treatment 141, 307-316 (2013).

25. Cahill, L.E., Sacks, F.M., Rimm, E.B. \& Jensen, M.K. Cholesterol efflux capacity, HDL cholesterol, and risk of coronary heart disease: a nested case-control study in men. J. Lipid Res. 60, 14571464 (2019).

26. Jensen, M.K., Rimm, E.B., Furtado, J.D. \& Sacks, F.M. Apolipoprotein C-III as a potential modulator of the association between HDL-cholesterol and incident coronary heart disease. Journal of the American Heart Association 1, e000232 (2012).

27. Mendivil, C.O., Rimm, E.B., Furtado, J., Chiuve, S.E. \& Sacks, F.M. Low-density lipoproteins containing apolipoprotein C-III and the risk of coronary heart disease. Circulation 124, 20652072 (2011). 